\title{
The New Grand Compromise: How Syrian Refugees Changed the Stakes in the Global Refugee Assistance Regime
}

\author{
Rawan Arar \\ University of California, San Diego \\ rarar@ucsd.edu
}

\begin{abstract}
The influx of asylum seekers in Europe in 2015 and 2016 changed the incentive structure of the "grand compromise" - the system of global refugee management in which states in the Global South host most of the world's refugees and states in the Global North finance refugee hosting abroad. Asylum seekers interrupted the established status quo, and in doing so, created new opportunities for states in the Global South. I argue that a "new grand compromise" emerged. Major refugee host states in the Global South, especially those with large Syrian refugee populations, were able to leverage the value of their refugee hosting capacity and renegotiate policies to promote statecentric agendas. I elaborate on the case of Jordan to illustrate how government officials strategically capitalized from the influx of asylum seekers in Europe, making Jordanian resilience and development an integral part of the global refugee response.
\end{abstract}

\section{Keywords}

refugees - asylum seekers - new grand compromise - Global North - Global South Europe - Jordan

The contemporary refugee crisis garnered unprecedented attention after the tragic drowning of Aylan Kurdi in September 2015. His image could not be ignored. A three-year-old Syrian boy lay face-down and lifeless on the Turkish shore, his round belly exposed against the wet sand. Aylan's tiny shoes and chubby cheeks captured the innocence of the struggle to stay alive. His family's effort to find refuge in Europe placed an onus on Western citizens to pay 
attention. Since the start of the Syrian conflict in 2011, millions of refugees from Syria had already been displaced to neighboring countries in the Middle East - but, Aylan's death put a face to the refugee crisis. His death humanized millions of people, mobilized actors around the world, and led to a cascade of policy changes. ${ }^{1}$

Sympathy was fleeting, however, as over one million people (mostly Syrians) arrived in Europe by sea in 2015. ${ }^{2}$ Asylum seekers who reached Western shores have been theorized to push the limits of liberal values ${ }^{3}$ but the events of 2015 marked a new experience all together. Not only did Europe see a break-down of established asylum institutions, but the world also faced the breakdown of established global refugee management mechanisms, mechanisms built on systems of interdependence between donor states in the Global North and major refugee host states in the Global South.

Donor states in the Global North were in a panic to maintain the status quo, which had until then reliably contained refugees in the Global South. New opportunities emerged for states with stakes at the negotiating table. In this paper, I chart how the grand compromise between the Global North and the Global South was maintained, but recalibrated. I argue that major refugee host states, predominantly those that received Syrians, were able to renegotiate the value of their hosting capacity. I call this the new grand compromise and elaborate on the case of Jordan to illustrate the increased value of refugee hosting. I identify how Jordanian government officials strategically capitalized from the influx of asylum seekers in Europe, and in doing so, also made Jordanian statecentric goals of resilience and development integral parts of the global refugee response.

1 For a discussion of refugee experiences in host states, see Basileus Zeno, "Dignity and Humiliation: Identity Formation Among Syrian Refugees," Middle East Law and Governance 9, no. 3 (2017): pp. 282-297.

2 UNHCR, "Refugees and migrants crossing the Mediterranean to Europe: Overview of arrival trends as of 14 September 2015," September 14, 2015, http://reliefweb.int/sites/reliefweb.int/ files/resources/Dashboard-seaarrivalsı4September.pdf; For a discussion of Syrian refugee reception in Germany, see Wendy Pearlman, "Culture or Bureaucracy? Challenges in Syrian refugees' initial settlement in Germany," Middle East Law and Governance 9, no. 3 (2017): pp. 313-327.

3 See Christian Joppke, "Why liberal states accept unwanted immigration," World politics $5^{0}$ (1998): 266-93; Rogers Brubaker, "Comments on 'Modes of Immigration Politics in Liberal Democratic States," International Migration Review 29, no. 4 (1995): 903-08; Gary Freeman, "Modes of Immigration Politics in Liberal Democratic States," International Migration Review 29 no. 4 (1995): 881-902. 


\section{The Original Grand Compromise}

Cuéllar ${ }^{4}$ describes the system of global refugee management as a grand compromise between states in the Global South and states in the Global North. States in the Global South host most of the world's refugees. In 2016, these states housed $84 \%$ of the world's 22.5 million refugees. ${ }^{5}$ Meanwhile, wealthier states in the Global North resettle less than one percent of all the world's refugees, but donate to states in the Global South to assist them with their refugee hosting efforts. The expectation that donor states can cap the number of refugees that are allowed onto their territory is integral to the grand compromise. Refugees must be selected, vetted, and screened before they can enter countries in Europe, the United States, Canada, or Australia.

Sovereignty is at stake in the grand compromise. The principle of sovereignty refers to a state's ultimate control within its specified territory, and its externally recognized right to claim legitimate authority over its internal affairs. ${ }^{6}$ Scholars empirically study sovereignty by considering how, and to what extent, a state can control its borders. Scholars also assess the extent of a state's authority over international institutions that seek to influence national-level governance. One important and recurring question characterizes the global distribution of refugees: How much is sovereignty worth?

The established international refugee regime prioritizes the sovereignty of states in the Global North at the expense of sovereignty in the Global South, precisely because the grand compromise was spearheaded by states in the Global North. States in the Global South host large and unpredictable numbers of refugees, which invites many urgent and long-term challenges. Abrupt demographic changes can place a strain on social institutions, crowding hospitals and schools. Large refugee flows can lead to new ethnic and religious demographics that can increase tensions between refugee and host communities or among citizens. ${ }^{7}$ Porous borders can also heighten threats to national

4 Mariano-Florentino Cuéller, "Refugee Security and the Organizational Logic of Legal Mandates," Georgetown Journal of International Law, Stanford Public Law Working Paper 37 no. 918320 (2006): 1-102.

5 "Global Trends: Forced Displacement in 2016. United Nation High Commissioner for Refugees" 2017, http://www.unhcr.org/globaltrends2016/.

6 See Michael Mann, "Has Globalization Ended the Rise of the Nation-State?" Review of International Political Economy 4 no. 3 (1997): 472-96; Anthony Giddens, The Nation-State and Violence (Berkeley: University of California Press, 1985).

7 For a discussion of the challenges of refugee hosting in Lebanon, see Lama Mourad, "Inaction as policy-making: Understanding Lebanon's early response to the refugee influx," Middle East Law and Governance 9, no. 3 (2017): pp. 249-266. 
security. ${ }^{8}$ Terrorism is one of the most serious contemporary threats, but other challenges arise too, including increased drug and weapon trafficking. Porous borders have also been cited as a public health concern. Infectious disease outbreaks can occur, especially when large numbers of people are confined to unhygienic living spaces, such as overcrowded refugee camps.

In addition, scholars posit that the involvement of international institutions like the UN (United Nations) or supranational institutions like the EU (European Union) contribute to the erosion of state sovereignty. ${ }^{9}$ While states in the Global North carefully manage international interference, states in the Global South must often rely on international institutions to provide emergency relief. Short-term challenges stretch into long-term problems as nearly $68 \%$ of the world's refugees have been displaced for five or more years in protracted refugee situations. ${ }^{10}$ This statistic does not include the 5.3 million Palestinian refugees who are registered with UNRWA and live in the Global South (United Nations Relief and Works Agency). States in the Global South invite the UNHCR (United Nations High Commissioner for Refugees) and other international aid agencies, to contribute to housing, feeding, and providing social services to refugees. Kagan characterizes the UNHCR as a "surrogate state," whereby the UN has state-like functions through its allocation of rights to refugees with the permission of the host state. ${ }^{11}$

The compromise is not abstract: States in the Global North pay money to contain refugee populations abroad and protect their sovereignty. These payments are often discussed as contributions to the UNHCR, but there are other important economic contributions including money given directly from one state to another and economic contributions that consider refugee reception but are primarily donated to support security interests abroad or shared development goals outside refugee-hosting concerns. Beyond state to state contributions, the European Union, which seeks to further the interests of

See Filippo Dionigi, "Rethinking borders: The dynamics of Syrian displacement to Lebanon," Middle East Law and Governance 9, no. 3 (2017): pp. 232-248.

See Saskia Sassen, "Beyond Sovereignty: De-Facto Transnationalism in Immigration Policy," European Journal of Migration and Law 1 no. 2 (1999): 177-198; Anthony H. Richmond, "Reactive migration: Sociological perspectives on refugee movements," Journal of Refugee Studies 6 no. 1 (1993): 7-24; Rawan Arar, "Leveraging Sovereignty: The Case of Jordan and the International Refugee Regime," POMEPS Studies 25 (2017): 12-15.

10 "Global Trends: Forced Displacement in 2016. United Nation High Commissioner for Refugees," 2017, http://www.unhcr.org/globaltrends2016/.

11 Michael Kagan, "We Live in a Country of UNHCR: The UN Surrogate State and Refugee Policy in the Middle East," The UN Refugee Agency: Policy Development \& Evaluation Serv., Research Paper no. 201 (2011): 1-25. 
European states, is also an important contributor of aid dollars to major refugee receiving states. Financial contributions can exist in the form of incentives, not just cash money. These incentives include the opening of Western markets to states in the Global South through renegotiated trade agreements and the relaxing of travel restrictions for citizens from the Global South to travel to the Global North as economic migrants, such has been the case with Morocco ${ }^{12}$ and Turkey. ${ }^{13}$

Demographic differences in refugee hosting influence practices of refugee and asylum integration. In the Global North, integration can be challenging, but the process of incorporation allows for political incorporation and a pathway to citizenship. This clearly provides stability and legal protection for refugees and asylum seekers, but also serves the interests of Western democratic states by creating a more unified polity and avoiding the chaos that often follows the influx of large numbers of refugees across borders. States in the Global North have generally avoided the widespread reliance on refugee camps, with few exceptions including Calais refugee and migrant camp in France. ${ }^{14}$

Political integration of refugees in the Global South is rare. One important shortcoming of the grand compromise can be understood as the disincentive that major refugee host states have to promote local integration. The responsibility to host people is more permanent than the stream of money coming in to finance hosting. Integration can lead to a weaning off from international aid dollars when refugees become the financial responsibility of the states in which they reside as opposed to the international community. States in the Global South, therefore, have been incentivized to impede local integration.

The influx of people into Europe in 2015 and 2016 changed the incentive structure of the grand compromise. States that host the majority of Syrian refugees found their "local absorptive capacity," which Jacobsen defines as the "ability" and "willingness" to host refugees, in even higher demand. ${ }^{15}$ Local integration in countries that host the majority of Syrian refugees became more valuable to donor states in the Global North as a method to deter forced migrants from reaching Europe.

12 Kelsey P. Norman, "Between Europe and Africa: Morocco as a country of immigration," The Journal of the Middle East and Africa 7 no. 4 (2016): 421-439.

13 Kemal Kirişci, "Europe's refugee/migrant crisis: can 'illiberal' Turkey save 'liberal Europe' while helping Syrian refugees?" European Policy Center (2016). http://www.epc.eu/ documents/uploads/pub_6324_europe_s_refugee-migrant_crisis.pdf.

14 Jessica Reinisch, "Forever Temporary': Migrants in Calais, Then and Now," Political Quarterly 86 no. 4 (2015): 515-522.

15 Karen Jacobsen, "Factors Influencing the Policy Responses of Host Governments to Mass Refugee Influxes," International Migration Review 30 no. 3 (1996): 655-678. 


\section{The New Grand Compromise}

Asylum seekers in Europe captured global headlines even though most of the world's refugees continued to live in developing countries. ${ }^{16}$ The problem of displacement was reimagined with Europe at the center. The questions that were asked, and the observations that were made, about refugee experiences were curated by European concerns: Are these people economic or political migrants? How will they integrate? How can Europe stop people from coming? The violence or lack of protections that catalyzed displacement and secondary refugee flows were often tangential to the social construction of the "refugee problem." Therefore, the search for solutions emphasized the needs of European states.

Rhetorically, the terms "Syrian Refugee Crisis" and "European Refugee Crisis" (both ubiquitous phrases) captured how different a "crisis" can be. Syrian refugees are fleeing an authoritative regime, barrel bombs, mandatory conscription, ISIs fighters, and the extreme poverty that has been exacerbated by the war. The violence was the impetus to flee: to leave behind one's home, extended family, assets, and way of life. Meanwhile, the "European Refugee Crisis" was not without its violent challenges including the death of thousands of asylum seekers at sea, ${ }^{17}$ the overcrowding conditions of those in spontaneous camps, and the uncertainty that characterized failing and developing asylum policies. Nationalistic concerns collided with moral imperatives. Europeans found themselves at the crux of a humanitarian crisis that destabilized and energized political systems. While both Syria and Europe face intractable challenges, to call both a "refugee crisis" obscures the violence and chaos that leads to displacement with the violence and chaos of poor reception.

16 Choosing between the terms refugee, asylum seeker, and migrant can be complicated. The legal definition of a refugee under the 1951 Refugee Convention can differ from the sociological definition of a refugee. Sticking to the legal definition (one that has been established in the interest of states not just displaced people) excludes an important subsection of people who have fled violence. Meanwhile, the term "migrant" neglects that many of these people may be fleeing persecution. I rely on the term "asylum seeker" to denote that these people may be fleeing violence, but their legal status is yet to be determined. See David FitzGerald and Rawan Arar, "What drives refugee migration?" Newsletter of the American Political Science Association (APSA) Section on Migration and Citizenship 4, no. 2 (2016): 7-12.

17 Amnesty International, "A perfect Storm: The Failure of European Policies in the Central Mediterranean," July 6, 2017, https://www.amnesty.org/en/documents/euro3/6655/2017/ en/. 


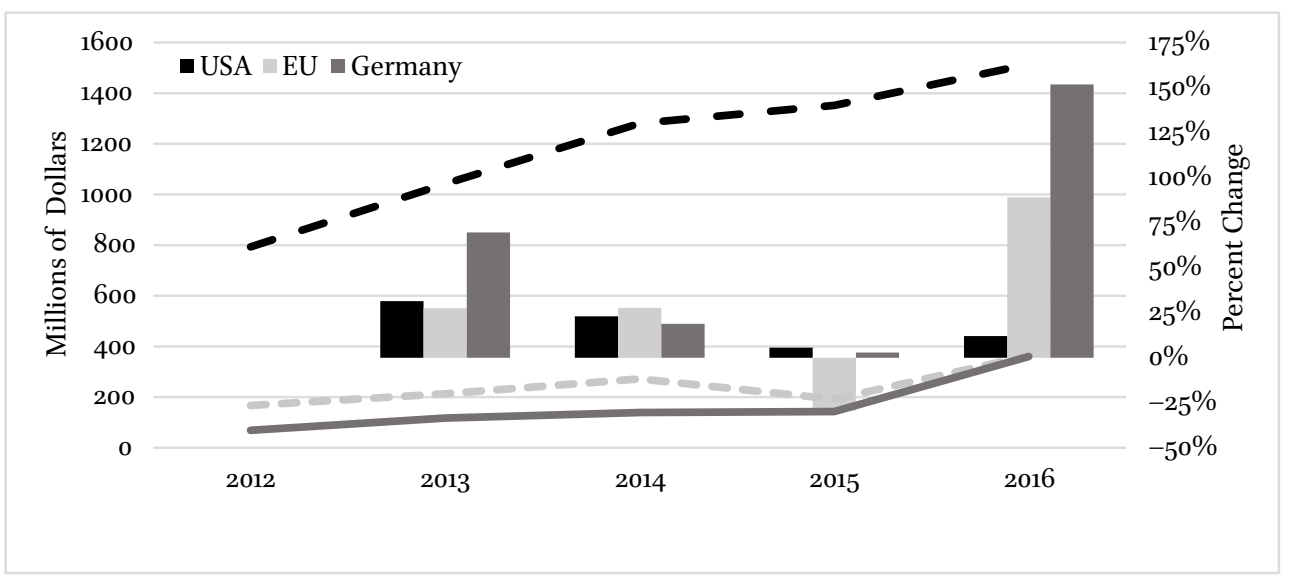

FIGURE 1 Top donor states to UNHCR in 2016 and percent change between consecutive years.

In 2016, European strategies of asylum deterrence abounded as economic and security concerns grew. When "burden sharing" strategies among EU states failed and the Dublin Regulation proved ill-equipped to manage large numbers of asylum seekers, the European strategy turned to "burden shifting" further placing the responsibility of refugee hosting onto the Global South. The impetus to stop refugees from reaching Europe led to a significant increase in aid dollars. Figure 1 shows the top donor states to the UNHCR in 2016. The line graph indicates the absolute number of dollars donated to the UNHCR, while the bar graph illustrates the percent change between consecutive years. Most notably, after the influx of asylum seekers to Europe in 2015, European aid dollars increased significantly.

Major refugee receiving countries in the Middle East, primarily Jordan, Lebanon, and Turkey, saw increased support not only funneled through the UNHCR, but also given directly to each state. In 2016, the EU and the international community pledged billions of dollars with the EU-Turkey deal, ${ }^{18}$ and EU compacts with both Jordan and Lebanon. ${ }^{19}$ The parameters of these agreements

18 Kim Rygiel, Feyzi Baban, and Suzan Ilcan, "The Syrian refugee crisis: The EU-Turkey 'deal' and temporary protection," Global Social Policy 16 no. 3 (2016): 315-320.

19 See Katharina Lenner, "The politics of pledging: reflections on the London donors conference for Syria," European University Institute MPC Policy Briefs no. 3 2016; Ali Bilgic and Michelle Pace, "The European Union and refugees. A struggle over the fate of Europe," 3 (2017): 89-97. 
clearly illustrate that refugee hosting is a good that donor states are willing to pay large sums of money for.

Integration became an important tool for deterrence. European reasoning was clear: If refugees are better able to integrate into major refugee receiving countries, they are less likely to travel to Europe in search of asylum. While there was little progress in terms of political integration and pathways to citizenship in the Global South, economic integration became a primary focus. ${ }^{20}$ Along with concessions that allowed for relaxed entry into European markets for Jordanians and laxer visa regulations for Turks, these agreements stipulated that major refugee host countries would make their states more hospitable to Syrian refugees.

Not all states in the Global South saw an equal appreciation of their refugee hosting capacity. According to the UNHCR, the major refugee host countries in 2016 were as follows: Turkey (2.9 million), Pakistan (1.4 million), Lebanon (1.0 million), Iran (979,400), Uganda (940,80o), and Ethiopia (791,60o) (Global Trends 2016). ${ }^{21}$ Without considering the conditions of donor states in the new grand compromise, one may expect that all these states would benefit substantially from increased attention to the global refugee crisis based solely on need. This was not the case.

States that host Syrian refugees, who make up most asylum claims in Europe (see Table 1), upstaged states that predominately host other refugee groups. Even though Africa saw a 20\% increase in refuge populations in $2015(728,500$ absolute number) and a 16\% increase in 2016 (721,700 absolute number), it did not attract the same amount of support as countries that hosted the refugee populations that sought refuge in Europe (Global Trends 2015; Global Trends 2016). This is further indication that the global refugee crisis was socially constructed as a Euro-centric problem; therefore, putting Global North states' interests over the needs of displaced persons.

Despite the clear terms of engagement in the new grand compromise, states in the Global South that did not host Syrian refugees tried to capitalize from the breakdown of the international refugee assistance regime. Major refugee host countries pivoted toward being viewed as transit countries, or more explicitly, as physical buffers to Europe. Their refugee hosting capacity was also marketed as the ability to halt secondary refugee movements. After the EUTurkey deal was announced, Kenyan government officials vowed to close the

\footnotetext{
20 Alexander Betts and Paul Collier, Refuge: Transforming a Broken Refugee System (London: Penguin Allen Lane, 2017).

21 Jordan is not included in this list because, for this assessment, Palestinian refugees were not included in the total.
} 
TABLE 1 Top 10 countries of origin of non-EU asylum seekers in the EU-28 Member States, 2015 and 2016 (thousands of first time applicants)

\begin{tabular}{lcc}
\hline & $\mathbf{2 0 1 5}$ & $\mathbf{2 0 1 6}$ \\
\hline Syria & 362.7 & 334.8 \\
Afghanistan & 178.3 & 183.0 \\
Iraq & 121.6 & 127.0 \\
Pakistan & 46.5 & 47.6 \\
Nigeria & 30.0 & 46.1 \\
Iran & 25.4 & 40.2 \\
Eritrea & 33.1 & 33.4 \\
Albania & 66.1 & 28.9 \\
Russia & 18.4 & 23.0 \\
& & \\
\hline
\end{tabular}

world's largest refugee camp. The intention to close Dadaab camp threatened to displace or refoule 245,126 refugees from Somalia. ${ }^{22}$ Implicitly, the closing of Dadaab also threatened further breakdown the established division of labor between states in the Global North and states in the Global South.

Pakistan also vied to benefit from the new grand compromise. Pakistani migration, which helped constitute mixed flows of migrants to Europe, gave the state leverage to compete for increased aid from Europe and renegotiate bilateral agreements with the EU. Pakistan hosts large numbers of Afghani refugees, but Pakistanis do not usually constitute refugee flows according to UNHCR statistics. As illustrated in Table 1, Pakistanis comprised the fourth largest group of asylum seekers to Europe. Though some Pakistanis were given asylum, most were rejected and deported. Notably, Pakistan made headlines when state officials refused to accept thirty migrants deported from Greece claiming that their identities could not be verified. ${ }^{23}$ Pakistani officials successfully renegotiated terms of aid with the EU. A Joint Press Communiqué released in 2016 read:

Both sides discussed migration and refugees issues. The Pakistan side underlined the need for addressing the root causes of migration and taking an integrated approach encompassing different aspects of migration.

22 UNHCR Refugees from Somalia, "Horn of Africa Somalia Situation," 2017, https://data2 .unhcr.org/en/situations/horn/location/179.

23 ввС, "Pakistan blocks 30 migrants deported from Greece," British Broadcasting Corporation, December 4, 2015, http://www.bbc.com/news/world-asia-35003261. 
The EU acknowledged the challenges faced by Pakistan in hosting over 3 million refugees and is ready to consider providing additional support, including for their repatriation to Afghanistan in safety and dignity. They agreed to further strengthen cooperation on migration issues, including irregular migration, and reaffirmed their commitment to the continued implementation of the EU-Pakistan Readmission Agreement. ${ }^{24}$

$3^{\text {rd }}$ EU-Pakistan Strategic Dialogue 2016

Written between the lines of this communiqué, Pakistan's refugee hosting capacity was leveraged in negotiating for increased development support for the state and its citizens. The breakdown of the original grand compromise did not change the disparities between states in the Global North and states in the Global South, but instead, gave states in the Global South the opportunity to renegotiate terms and conditions. These states had the most to gain from the influx of asylum seekers in Europe.

\section{Jordan's Golden Year}

Jordanian officials leveraged their country's role in solving the European "refugee problem," and in the process, significantly increased international support for refugees and citizens. Jordan has historically been a leader in refugee hosting, playing a central role in the original grand compromise. For over 70 years, Jordan has hosted displaced people from Palestine, Iraq, and Syria, to name only the most prominent waves of refugees. The state has continuously earned recognition as one of the UNHCR's top ten refugee host countries, even when the over two million Palestinian refugees registered with UNRWA are not included in UNHCR host statistics.

According to the UNHCR, approximately 655,500 Syrians refugees are registered with the UN. Governmental estimates are much higher, suggesting that Jordan hosts 1.3 million Syrians. One operative distinction between the two institutions is the difference between "Syrian refugees" and "Syrians." Governmental estimates include both "Syrian refugees" registered with the UN and "Syrians" who may have been in Jordan before the start of the conflict. While the governmental estimate is often cited by state officials, the UN HCR number is used as the operational measure that influences intervention. In 2015, Jordan

24 "Joint Press Communiqué - 3rd Eu-Pakistan Strategic Dialogue," Brussels, 4 October 2016, https://eeas.europa.eu/headquarters/headquarters-homepage_en/11038/3rd\%20 EU-Pakistan\%20Strategic\%2oDialogue. 
was also the top country of UNHCR resettlement operations with 24,374 refugees submitted for resettlement. Therefore, Jordan is not only a major refugee host country in the Global South, but also a major country of first settlement, which further emphasizes Jordan's role in the distribution of refugees to the Global North.

One Jordanian official described 2016 as "Jordan's golden year," indicating that this would be the year Jordanian officials would best be able to advocate for Jordanian interests. Refugees were making global headlines and Jordan's role in hosting refugees was gaining prominence. He explained that it would be in Jordan's interest to emphasize the country's role as a "buffer state" like Turkey, despite the clear geographic differences. Jordan is almost completely landlocked with no direct pathway to Europe. Still, according to this official, 150,00o Syrians have returned to their home country since the start of the Syrian refugee crisis in 2011. He suggested that, while there is no way to know the exact number of people, many of the Syrians that returned may have made secondary trips from Syria to Europe. Hence, he reasoned, Jordan serves as a buffer state to Europe.

"We should have blackmailed the Eu like Turkey did," my respondent lamented, referring to the EU-Turkey deal. While he criticized Turkey's impolite behavior toward the European Union, he recognized that Turkey had more successfully leveraged their refugee hosting capacity to gain greater resources from donor states in the Global North. The EU agreed to give Turkey €6 billion to support Turkey's continued refugee hosting and support visa-free travel for Turkish citizens to the Schengen zone. In exchange, Turkey would receive deported individuals that traveled to Europe as part of a one-for-one trade agreement. For each person sent to Turkey, the EU agreed to resettle an asylum seeker. ${ }^{25}$

The terms of Jordan's renegotiated role in the new grand compromise emerged from the 2016 London Conference. The Jordan Compact outlined the international community's responsibility in supporting Jordan's hosting of Syrian refugees. Notably, other refugee populations, including Iraqis and Gazans, were not included in the negotiated expansion of social rights and support to the state. Jordan pledged to promote Syrian economic and social integration by providing "200,000 job opportunities" for Syrians and to support Syrian education through the "Accelerating Access to Quality Formal Education" plan.

25 Amnesty International, "The Eu-Turkey deal: Europe's year of shame," March 20, 2017, https://www.amnesty.org/en/latest/news/2017/o3/the-eu-turkey-deal-europes-year-of -shame/. 
In exchange for Jordan's commitment to Syrian refugees, the European states vowed to relax the rules of origin trade requirements, further opening EU markets to Jordanian goods, and offered considerable financial support:

Pledges made in London amount to around $\$ 700$ million of grants in support of the Jordan Response Plan for 2016 ... Additional pledges already made will contribute to the aim of providing around $\$ 700$ million in grants for 2017 and 2018 too ... The Multilateral Development Banks have identified the potential to increase their financing from $\$ 800$ million to $\$ 1.9$ billion ... Additional pledges of around $\$ 300$ million of grant or grant equivalent have already been made. More is expected.... ${ }^{26}$

JORDAN COMPACT 2016

For European states, an important impetus for the London Conference and the Jordan Compact was to deter Syrian refugees from migrating to Europe by improving living conditions in Jordan. Integration became a tool for deterrence. For Jordanians, however, the objective was to emphasize that refugee hosting has far reaching consequences that negatively affect Jordanian citizens and infrastructure. These concerns appear throughout the Compact, as exemplified by the following sentence: "Jordanians need to see that the international community is not prioritising support to refugees to their detriment." Refugee aid, Jordanians reasoned, must also support Jordanian resilience.

The contemporary Jordanian strategy to hosting Syrian refugees, and for acquiring and allocating international aid, is to focus on Jordanian resilience and development. The Jordanian Ministry of Planning and International Cooperation (MOPIC) is charged with approving and funneling all international aid that comes into the country. Each year since 2014, MOPIC has organized stakeholders to set a three-year agenda for refugee support and Jordanian resilience. The Jordanian agenda is outlined in a document entitled the Jordanian Response Plan (JRP). The 2017-2019 JRP reads:

Through the Jordan Compact, the government sought to transform the refugee crisis into a development opportunity that attracts new investments and opens up the EU market with simplified rules of origin, thus

26 "The Jordan Compact: A New Holistic Approach between the Hashemite Kingdom of Jordan and the International Community to deal with the Syrian Refugee Crisis," 2016, http://www.oecd.org/officialdocuments/publicdisplaydocumentpdf/?cote=DCD/DAC/ $\mathrm{RD}(2016)$ 7/RD1\&docLanguage $=$ En. 
creating jobs for both Jordanians and Syrian refugees in a complimentary, non-competitive manner to Jordanian job creation

2017-2019 JRP; vi; emphasis is mine. ${ }^{27}$

The push for development described above is further exemplified by the distinct categories across which Jordanian officials budget international aid. For each sector affected by the refugee crisis, such as education, energy, health, and shelter, there are budget allocations earmarked for either the "refugee response" or the "resilience response." This distinction considers the challenges that refugee hosting places on Jordan which cannot be alleviated by direct support for refugees. For example, zero dollars are budgeted under "refugee response" for the categories of environment, transport, and management. These issues are fully part of the "resilience response." Meanwhile, significantly more money is budgeted for refugee food security as compared to food security under the "resilience response" category.

Even though Jordanians made concessions allowing for limited Syrian integration (which was previously a red-line issue), all concessions were constrained by citizens' concerns and tied to development goals. Syrian employment, for example, was made conditional upon Jordanian employment and advancement. King Abdullah II made his country a remarkable promise: for every job offered to a Syrian refugee, there would be five jobs created for Jordanians. ${ }^{28}$ There were also strict limitations placed on the kinds of jobs that Syrians could occupy. Syrians' work opportunities were largely limited to the garment sector with handicrafts and textiles, construction, the service industry, and janitorial work. As of January 2017, 44,900 work permits were issued to Syrian refugees, a fraction of the 200,000 work permits pledged by Jordanian officials. ${ }^{29}$

Restrictions in employment opportunities have far reaching effects beyond economic opportunities; these restrictions affect social mobility as well. As one NGO representative reasoned, "Why should children aspire to become doctors,

27 "The Jordan Response Plan for the Syria Crisis 2017-2019," 2017, https://static1 .squarespace.com/static/522c2552e4bod3c39ccdieoo/t/587225b917bffcdo586b3bc4/14838 75842114/20170108JRP+2017-2019+-+Final+Draft.pdf.

28 Rana F. Sweis, "Jordan Struggles Under a Wave of Syrian Refugees," New York Times https:// www.nytimes.com/2016/o2/14/world/middleeast/jordan-syria-refugees.html?mcubz=0.

29 ILO, "Work Permits and Employment of Syrian Refugees in Jordan: Toward Formalising the Work of Syrian Refugees," International Labour Organization, 2017, http://reliefweb .int/report/jordan/work-permits-and-employment-syrian-refugees-jordan-towards -formalising-work-syrian. 
lawyers, and engineers when the best they can hope for is a low-skilled job?" While one may argue that an education is inherently valuable, my respondent heard this sentiment repeated several times by Syrian students and their parents. After all, in cases of extreme poverty, an education has opportunity costs. Some families prioritized child labor over school attendance to help make ends meet. The increase in social rights for Syrian refugees, predominantly in the employment and education sectors, are stunted by high rates of Jordanian unemployment and growth constrains in the Jordanian educational system.

Despite the lofty and historic promises written into the Jordan Compact, the gap between policy and practice remains a challenge. Some of these issues may come from the obstacles that impede on-the-ground interventions. However, diverging interests between negotiating parties - in this case, between European states and Jordan - are rooted in distinct social constructions of the "refugee problem." European states see the "refugee problem" as one that can be solved through integration as deterrence. Syrian integration into Jordanian society may stymie secondary refugee flows to Europe. Meanwhile, Jordanians see the "refugee problem" as one that strains social institutions and impedes development goals. Jordanian solutions to the refugee problem incorporate Jordanian resilience as essential; therefore, these interventions hold the international community responsible for refugee aid and alleviating the challenges of refugee hosting.

\section{Conclusion}

The influx of asylum seekers to Europe in 2015 and 2016 upended the established division of labor that characterized the relationship between states in the Global North and states in the Global South known as the grand compromise. A new grand compromise emerged as major refugee receiving states in the Global South gained leverage over states in the Global North that were urgently interested in deterring refugees and asylum seekers, controlling their borders, and maintaining sovereign interests. States in the Global South - predominantly those that received Syrian refugees - found their refugee hosting capacity in high demand. While disparities between states remained intact, countries in the Global South were better able to advocate for themselves to increase international aid, promote economic development, relax travel restrictions for citizens, and ameliorate the challenges of hosting large numbers of refugees. As scholars investigate contemporary policy changes and evolving refugee experiences, many questions remain unanswered, including: Will donor states invest further in supporting refugees abroad to preempt the 
events of 2015 and 2016? What will be the long-term effects of the new grand compromise?

Some refugees will surely benefit from these new measures. However, it must be noted that these are negotiations among states and international or supranational institutions - refugees are not provided a place at the negotiation table. Ironically, the opportunity to renegotiate the grand compromise, and the increased leverage that states in the Global South enjoyed as part of the new grand compromise, was a direct result of asylum seekers' agentic actions to seek refuge in Europe. ${ }^{30}$

3o For discussions of refugee agency beyond the "victim" or "warrior" construct, see Rana Khoury, "Activism among Syrian Refugees in Jordan," Middle East Law and Governance 9, no. 3 (2017): pp. $267-281$. 